\title{
ГРАЖДАНСКОЕ ПРАВО.
}

ПРЕДПРИНИМАТЕЛЬСКОЕ ПРАВО.

СЕМЕЙНОЕ ПРАВО.

МЕЖДУНАРОДНОЕ ЧАСТНОЕ ПРАВО

\section{РАЗВИТИЕ ПОНЯТИЯ «МОРАЛЬНЫЙ ВРЕД" В ОТЕЧЕСТВЕННОМ ЗАКОНОДАТЕЛЬСТВЕ}

\section{Сакаева К.У.}

Аннотация: Понятие «моральный вред» занимает главное место при изучении института компенсации морального вреда, под которым понимается как страдания, физические и нравственные личения, причиненные лицу неправомерными действиями и представляет собой самостоятельный институт морально-нравственной защчиты лица. Рассматриваемое понятие включает в себя моральные категории, которые сформировались у человека с развитием общества и которые были известны давно, о чем мы находим подтверждение у философов древности. Безусловно, эти понятия претерпевали эволюиионные изменения, но содержание их не менялось: зло, нравственность, мораль, культура и другие. Методология: диалектика, абстрагирование, анализ, синтез, дедукиия, формально-юридический метод, сравнительно-правовой и статистический методы, метод межотраслевых юридических исследований Под моральным вредом в трудовом праве следует понимать причинение работнику физических и нравственных страданий, возникших в силу нарушений или несоблюдения трудового законодательства со стороны работодателя, приведшее к деформации трудовых отношений и требующий компенсации в формах: денежной, предоставлении компенсационных услуг (возмещение затрат, связанных с получением работников образования), выборной (применительно к имеющимся возможностям работодателя).

Ключевые слова: Моральный вред, возмещзение, преступление, республика, юридическое лицо, компенсация, мораль, гражданское законодательство, гражданский кодекс, психофизическое существо.

Понятие «моральный вред» занимает главное место при изучении института компенсации морального вреда, под которым понимается как страдания, физические и нравственные лишения, причиненные лицу неправомерными действиями и представляет собой самостоятельный институт морально-нравственной защиты лица. 
Рассматриваемое понятие включает в себя моральные категории, которые сформировались у человека с развитием общества и которые были известны давно, о чем мы находим подтверждение у философов древности. Безусловно, эти понятия претерпевали эволюционные изменения, но содержание их не менялось: зло, нравственность, мораль, культура и другие. Именно понятие «зло» было положение в основу института «моральный вред». «Зло» как философская категория шире понятий «физический вред»и «нравственные страдания». Последствием зла являются и причиненный вред здоровью, жизни. Этимологически под понятием «моральный» понимается «внутренний, душевный»[1]. Следовательно, под моральным вредом понимается «душевный вред», который относится к внутренней стороне жизни человека, стороне самой морали и вытекающей из нее нравственности, т.е. в силу пренебрежения соблюдать правила нравственности, в рамках которых существуют люди и отношения между ними, и возникает то «зло», которое противопоставляется «добру». Таким образом, моральный вред - это последствия, причиненные «добру» «злом». Здесь возникает вопрос: как разделить такие два разные понятия как «моральный» и «аморальный»? Дело в том, что принятая в обществе система норм морали не является четко зафиксированной. Поэтому часто можно встретить рассуждения о том, что для одних людей представляется «добром», а для других - «злом». Хотя есть определённые нормы морали, безусловно, которые для всех будут являться «злом».
В отличии от норм права, на нормы морали в большей степени влияют личные интересы, что, в свою очередь, не делает четким понятие «аморального». Особенно, если речь идет не о поступках, а поведении. А.П. Скрипник писал: «Безнравственные люди (злодеи) не составляют особой категории граждан и не обладают явными социологическими признаками, позволяющими осуществить их идентификацию»[2]. Поэтому выделить этих людей в отдельную и самостоятельную категорию просто невозможно еще и потому, что только в силу конкретных обстоятельств может проявиться поведение, причинившее страдания и приведшее к тем последствиям, за которые наступает возможность взыскания материальной компенсации. Это поведение проявляется в отношении законопослушных и добропорядочных граждан, поэтому и возникает вопрос их защиты.

В обыденной жизни многие люди испытывают страдания: душевные переживания, унижения, оскорбления, эмоциональные потрясения, неприятности. Эти страдания можно отнести к «бытовым». Страдания, за которые наступает необходимость компенсации, должны быть признаны вредными и должны «препятствовать целесообразной деятельности по удовлетворению моральных потребностей»[3].

Мораль - часть культуры человека. Мораль предписывает возможность противопоставлять: с одной стороны посредством совершенствования собственных способностей, ориентируясь на окружающих, с другой - использовать окружающих в соответствии с по- 
ставленной целью. При использовании окружающих и может быть причинено «зло», но не всегда, а только тогда, когда «взаимоотношения противоположностей приносят человеку разрушения в его душе, теле, среде обитания или имеют иное отрицательное значение для всего человечества»[3]. Причем, данное «зло» может проявиться как «физическое», так и «социальным».

Моральное «зло» вытекает из индивидуальной вины, свободы и ответственности и является следствием противоречивости самой морали, культуре и нравственности, а не является внешним в этим категориям. Оно существует самостоятельно и ставит целью причинение вреда таким ценностям человеческого общежития как жизнь, здоровье, репутация человека и т.п. Нормы морали наряду с нормами права призваны защитить человека от «зла», минимизировать его в жизни отдельного человека и общества в целом. Проявление «зла» в любой форме порождает вред, причиняемый конкретному человеку и, как следствие, возникает моральный вред. Следует согласиться с мнением О.В. Дашко, что «...моральное зло - это объективное понятие, а вот моральный вред - это субъективное понятие зла. Пока зло, причиненное субъекту, не будет этим субъектом осознано, оно не примет облик морального вреда, нуждающегося в защите»[3].

Действующее гражданское законодательство разработало свое понятие «моральный вред», основываясь на понятии «зла» в философии. Так, ГК РФ содержит нормы, регулирующие вопросы компенсации морального вреда.
Говоря о моральном вреде, мы не может не рассмотреть то, что его составляет, в частности, страдание как сложное психическое явление, переживаемое человеком. Страдание связано с причинением человеку боли, мучения. Именно так оно определяется в Толковом словаре русского языка: «страдание есть физическая или нравственная боль, мучение»[4], а боль, в свою очередь, тесно связано с «ощущением страдания»[4].

ГК РФ рассматривает два вида страданий: нравственные и физические. Но всем им присущи одни и те же признаки, которые устанавливаются судом и все они связаны с поведением человека и его психическим состоянием. Среди таких признаков в можно выделить: расстроенный и печальный вид, ощущение одиночества, пребывание в подавленном настроении, снижение физического тонуса, нарушение сна, аппетита и т.д.

Представляется вполне обоснованным применение законодателем слова «страдание» как ключевого в определении морального вреда. Термин «страдание» предопределяет, что действия причинителя такого вреда обязательно должны проявиться в сознании потерпевшего, вызвать определенную психическую реакцию.

Наиболее обоснованным является определение морального вреда как «нравственных страданий», содержанием которых может быть страх, стыд, унижение. Рассматривая вопрос о том, могут ли быть нравственные страдания вредом в правовом смысле, следует обратиться к положениям психологической науки. 
Право гражданина на компенсацию морального вреда впервые было установлено в Законе СССР от 12.06.1990 г. «О печати и других средствах массовой информации», в котором«моральный (неимущественный) вред, причиненный гражданину в результате распространения средством массовой информации не соответствующих действительности сведений, порочащих честь и достоинство гражданина либо причинивших ему иной неимущественный ущерб, возмещается по решению суда средством массовой информации, а также виновными должностными лицами и гражданами» (ст. 39). Что касается определения размера возмещения морального вреда, то он определяется судом и в денежном выражении.

Прорывом в законодательном закреплении института компенсации морального вреда явилось принятие Основ гражданского законодательства Союза ССР и республик от 31.05.1991 г. (далее - Основы), в ст. 131 которых, в частности, было предложено определение морального вреда и критерии его возмещения. Так, под моральным вредом понималось «причинение гражданину физических и нравственных страданий». Исходя из данного определения, моральный вред мог быть причинен только физическому лицу, т.к. перечисленные страдания (физические и нравственные) может испытать лишь психофизическое существо, а не социальное, к которому относится юридическое лицо. В отношении определения условий компенсаций морального вреда, то к ним относились противоправные действия, причинившие вред и вина со стороны причинителя этого вреда. Также в Основах предусматривалось, что моральный вред может компенсироваться как в денежной, так и в иной материальной форме. Размер компенсации определялся судом вне зависимости от подлежащего возмещению имущественного вреда.

Основы предусматривали компенсацию морального вреда не только физическому, но и юридическому лицу, когда речь шла о распространении сведений, порочащих их честь, достоинство, деловую репутацию. При этом, «компенсация морального вреда предусматривалась независимо от того, причинен ли этот вред посягательством на личное неимущественное право или на имущественное право потерпевшего лица»[5].

Данная нормы Основ действовали вплоть до 1995 г., когда понятие «моральный вред», а также условия его наступления и порядок компенсации были закреплены в ГКРФ. Несмотря на то, что в ГК РФ моральный вред определяется также, как и в Основах: «причинение гражданину физических и ли нравственных страданий» (ст. 151 ГК РФ), законодатель по другому определяет случаи причинения морального вреда. Так, если моральный вред причинен гражданину в результате посягательства на принадлежащее ему нематериальное благо, то он (потерпевший), при наличии условий, предусмотренных действующим законом, компенсируется в независимости от того, предусмотрена данная компенсация в законе. Иными словами, в приведенном случае основанием для компенсации морального вреда служит положение ст. 151 ГК РФ[5]. 
Большие споры ведутся и по сей день в отношении отраслевой принадлежности правовых отношений, связанных с возмещением морального вреда. Значительный период эти отношения рассматривались юридической наукой как гражданско-правовые. Но после принятия Президиумом Верховного Суда СССР Указа от 2 октября 1961 г. «О порядке рассмотрения споров о возмещении предприятиями, учреждениями, организациями ущерба, причиненного рабочим и служащим увечьем либо иным повреждением здоровья, связанным с их работой» и вступлением в силу Правил возмещения предприятиями, учреждениями, организациями ущерба, причиненного рабочим и служащим увечьем либо иным повреждением здоровья, связанным с их работой. Именно это послужило основанием рассматривать возмещение морального ущерба в плоскости трудового права. Но такая позиция вызвало и немало дискуссий, в том числе и крайне негативных.

Важное значение имело принятое Пленумом Верховного Суда РФ постановления от 20.12.1994 г. №10 «Некоторые вопросы применения законодательства о компенсации морального вреда», которое дало развернутое определение понятия «моральный вред», под которым следовало понимать «...нравственные или физические страдания, причиненные действиями (бездействием), посягающими на принадлежащие гражданину от рождения или в силу закона, нематериальные блага (жизнь, здоровье, достоинство личности, деловая репутация, неприкосновенность частной жизни, личная и семейная тайна и т.д.) или нарушающими его личные неимущественные права (право на пользование своим именем, право авторства и другие неимущественные права в соответствии с законами об охране прав на результаты интеллектуальной деятельности), либо нарушающими имущественные права гражданина» [6].

Применительно к трудовым отношениям, принятие рассматриваемого Постановления не только впервые раскрывало понятие «моральный вред», но и трактовала случаи компенсации морального вреда, правда путем применения аналогии ГК РФ. Так, то обстоятельство, что в законе может отсутствовать прямое указание на возмещение морального вреда, не означает, что такого права лишается потерпевший (п. 4 Постановления). В Постановлении разъясняется, что в подобном случае суд вправе поставить в обязанность работодателя компенсировать работнику причиненный моральный вред, выраженный в виде нравственных, физических страданиях, которые возникли от действий работодателя и связаны, например, с незаконным увольнением, необоснованным отказом от перевода на другую работу, необоснованным наложением дисциплинарного взыскания и т.д.

Таким образом, было установлено единообразие в практике применения норм закона, относящихся к компенсации морального вреда, возникающего в трудовых спорах и суды стали смело применять нормы гражданского права в части компенсации морального вреда в случаях нарушения трудовых прав.

В ТК РФ не содержит ограничения для компенсации морального вреда, 
поэтому его возмещение возможно и тогда, когда имеет место нарушение имущественных прав работнику, связанное с неполной или несвоевременной выплатой причитающихся ему денежных средств. Поэтому, неправильно считать, что в случае систематических не выплат работникам бюджетной сферы (учителя, врачи и др.) своевременно заработанной платы в полном объеме речь идет о возмещении материального ущерба, поскольку предметом нарушения являются имущественные права. Но, причиняя имущественный вред, работник претерпевает другие издержки - издержки нравственного характера: лишен возможности планировать расходы, претерпевает унижение чести и достоинства и т.д. И эти издержки требуют нравственной оценки и оценки компенсации морального вреда.

Важно, что нормы ТК РФ в части компенсации морального вреда распространяются и на военнослужащих и сотрудников полиции, несмотря на то, что сфера их деятельности регулируется Федеральными законами (Ф3 РФ «О воинской обязанности и военной службе»и ФЗ РФ «О полиции»). Рассматриваемая категория лиц может подать в судебные органы заявление с требованием возмещения морального вреда, который был нанесен вследствие: полученной травмы, контузии, ранения; получивших заболевания в период прохождения службы или в течение года после увольнения).

Сегодня возмещение морального вреда есть самостоятельный универсальный способ обеспечить защиту трудовых прав работника, который распространяется на все права, ох- ваченные трудовыми отношениями, причем, как закреплёнными в законодательстве, так не закреплённые (например, локальный нормативноправовой акт, трудовой договор).

Разъяснения по оценки степени нравственных или физических страданий дает Постановление Пленума Верховного Суда РФ от 20.12.1994 г. №10 в ред. от 06.02.2007 г. «Некоторые вопросы применения законодательства о компенсации морального вреда». В частности, данная оценка дается судом с учетом фактических обстоятельств причинения морального вреда, индивидуальных особенностей потерпевшего и других обстоятельств, которые свидетельствуют о тяжести перенесенных им страданий. Применительно к трудовым отношениям, факт причинения работнику морального вреда и установление размера денежной компенсации определяются судов независимо от возмещения ему материального ущерба (например, в случае причинения ущерба, предусмотренные ст. ст. 234, 235, 236 ТК РФ).

Большая часть поступающих в судебные органы заявления, предметом которых являются разногласия, возникающие в сфере регулирования трудовых споров, содержат и требования возместить моральный вред. Рассматривая такие заявления, суды, как мы уже отмечали, руководствуются наличием факта причинения работнику страданий (физических или нравственных) незаконными действиями работодателя, а также виной самого работодателя, при условии, если речь не идет о причинении физических и нравственных страданий вследствие причинения вреда жизни или 
здоровью работника (в данном случае, моральный вред должен быть возмещен вне зависимости от вины). Предъявляемые требования о возмещении морального вреда должны быть разумными и справедливыми (п.63 Пленума Верховного Суда Российской Федерации от 17.03. 2004 г. №2 «О применении судами Российской Федерации Трудового кодекса Российской Федерации»).

Под моральным вредом в трудовом праве следует понимать причинение работнику физических и нравственных страданий, возникших в силу нарушений или несоблюдения трудового законодательства со стороны работодателя, приведшее к деформации трудовых отношений и требующий компенсации в формах: денежной, предоставлении компенсационных услуг (возмещение затрат, связанных с получением работников образования), выборной (применительно к имеющимся возможностям работодателя).

\section{Библиография:}

1. Ожегов С.И. Словарь русского языка. М.: «Русский язык», 1986. С. 310.

2. Скрипник А.П. Моральное зло в истории этики и культуры. М.: «Политическая литература», 1992. С. 5.

3. Дашко О.В. Моральный вред и особенности его компенсации за нарушение авторских прав и смежных прав. Дис. ... канд. юр. наук. М., 2006. С. 29.

4. Ожегов С.И. Словарь русского языка. М., 1998. С. 47.

5. Гражданское право. Часть I / Под ред. Ю.К. Толстого, А.П. Сергеева. М.: ТЕИС, 1996. С. 328.

6. Российская газета от 8 февраля 1995 г. С. 5.

\section{References (transliterated):}

1. Ozhegov S.I. Slovar' russkogo yazyka. M.: «Russkii yazyk», 1986. S. 310.

2. Skripnik A.P. Moral'noe zlo v istorii etiki i kul'tury. M.: «Politicheskaya literatura», 1992. S. 5.

3. Dashko O.V. Moral'nyi vred i osobennosti ego kompensatsii za narushenie avtorskikh prav i smezhnykh prav. Dis. ... kand. yur. nauk. M., 2006. S. 29.

4. Ozhegov S.I. Slovar' russkogo yazyka. M., 1998. S. 47.

5. Grazhdanskoe pravo. Chast' I / Pod red. Yu.K. Tolstogo, A.P. Sergeeva. M.: TEIS, 1996. S. 328.

6. Rossiiskaya gazeta ot 8 fevralya 1995 g. S. 5. 